Kroeber, in a progress report covering the work of the Survey to April, 1939 (Anthropological Records, $1: 7$, Culture Element Distributions, 11, 1939, University of California Press), records that between 1934 and 1938 twenty trips to indigenous groups of peoples were made by 13 different observers, who brought back 279 filled-in lists of elements. In these there are now at least half a million of particularized and localized items of cultural fact, or if the supplemental notes are included, the number may well be nearer a million. Although several monographs already have been published, the great bulk of this material awaits computation. Not only does this task seem beyond human capability as a practical method of comparative ethnographic study, but also Prof. Kroeber now records that experience in the field, as well as in the study, counsels a reversal of method, at least to a major degree, in a return to the observational records of the more orthodox ethnographer.

\section{Anglo Soviet Journal}

THIs new journal has been started with the purpose of supplying "the more scientifically skilled and specialized workers in the British Commonwealth with a regular flow of information, accurate and reliable, on the progress and developments that are being realized in the U.S.S.R., in their own field, the field which they understand best". Very wisely the first issue is largely devoted to accounts of exhibitions, particularly of the great Agricultural Exhibition held in Moscow last summer, which was unquestionably the most magnificent effort of its kind the world has ever seen. Dictatorships are based on propaganda, and the Russians are the acknowledged leaders of the world in this new art. The design of the Exhibition was coherent and logical: the products of each region were brought together into separate pavilions, and each of the chief products had also its own special arrangements for show. The architecture was impressive and striking: no one could possibly forget the huge statue at the gate or the tower just inside, or the beauty of some of the pavilions.

The visitors included parties of peasants, some in picturesque local costume from all parts of the Union; many of them saw their own photographs hung up as good workers who had achieved more labour days than their fellows. More attention was paid to records than to average performanses. Special notice was given to the effort of two farm workers, Okhota and Chalova, in getting forty-one tons of sugar beet per acre (the average for England and Wales is about ten tons). How far the Exhibition reflects actual performance in the countryside cannot be determined, as no detailed statistics of yield or total production have been published so far as we know since 1935, though there are some figures for the bumper year of 1937 : but that is not the question. A forecast is given of the results anticipated from the proposed Trans-Volga irrigation scheme which, if it matures, and is free from too much complication of water-logging and salt, should produce food in a region where but little is grown now.

\section{France's Colonial Problems}

IN an address on "The Establishment of an Imperial Economy" (Bull. Soc. d'Encouragement pour l'Industrie Nationale, October 1939), M. E. du Vivier de Streel discusses the dependence of France on her colonial resources. He stresses the importance of science and technology in colonial development and the necessity of placing larger resources at the disposal of scientific organizations and technical men for the investigation of colonial problems, whether in improvement of agriculture, the prevention or control of disease, or the opening up of mineral resources. Such work should not be left precariously at the mercy of any local drive for economy. M. du Vivier de Streel refers also to the importance of population questions, education and a policy of public works, but while covering briefly much the same ground as the "African Survey" of Lord Hailey, he makes no reference to that outstanding work.

\section{Studentship for Psychical Research}

Trinity College, Cambridge, has established a studentship for the study of psychical research, out of a bequest left to the College for that purpose by Mr. F. D. Perrott as a memorial to F. W. H. Myers. Psychical research is defined, for this purpose, as "the investigation of mental or physical phenomena which seem prima facie to suggest $(a)$ the existence of supernormal powers of cognition or action in human beings in their present life, or $(b)$ the persistence of the human mind after bodily death". The studentship is open to any person who shall have completed his or her twenty-first year at the time when the election takes place. The studentship is tenable for one year, but a student may be re-elected once, but not more than once. The studentship will be of such value, not exceeding $£ 300$, as the electors may award after considering the nature of the research which the candidate proposes to undertake. Further information can be obtained from Prof. C. D. Broad, Trinity College, Cambridge.

\section{January Earthquakes Registered at Kew}

DuRIng January 1940 thirteen earthquakes were well registered by the seismographs at Kew Observatory. The largest of these were on January 6 at 14h. 23m. 2s. and January 17 at $1 \mathrm{~h}$. $33 \mathrm{~m}$. 24s., though a doubtful phase preceded this at $29 \mathrm{~m} .35 \mathrm{~s}$. This latter shock was registered at De Bilt (Holland) at $33 \mathrm{~m}$. 16s. G.C.T., and the shock of January 26 was also well observed there. The United States Coast and Geodetic Survey in co-operation with Science Service and the Jesuit Seismological Association has determined the epicentre of the earthquake of January 6 to have been lat. $22^{\circ} \mathrm{S}$., long. $170^{\circ} \mathrm{E}$. with initial time 14 h. $3 \cdot 4$ m. G.C.T. This determination was based on observations of seismograms obtained at Georgetown, Sitka, Apia, Honolulu, Pasadena, Fordham, San Juan and Manila. The provisional epicentre was in a well-known seismic zone of the Pacific Ocean to the east of the island of New Caledonia. The earthquake of January 17 was found by the same authority on the basis of 
reports from nineteen observatories to have been provisionally centred at lat. $17^{\circ} \mathrm{N}$., long. $148^{\circ} \mathrm{E}$., and to have had initial time $1 \mathrm{~h} .14 \mathrm{~m}$. 53s. G.C.T. This epicentre was in the Pacific Ocean to the east of Zealandia Bank (Marianas Islands).

\section{The Night Sky in March}

The time of the spring equinox is March $2018 \mathrm{~h}$. when the sun enters the sign Aries. The moon is new on March 9 and full on March 23. Lunar conjunctions with the planets occur as follows: March 11d. 8h., Jupiter : 12d. 14h., Saturn: 12d. 23h., Venus : 14d. 0h., Mars. It will be seen from these times that the grouping of the bright planets is still a conspicuous feature of the western sky after sunset, although Jupiter is being lost to view as the month proceeds. On March 8d. 14h., Venus is in conjunction with Saturn, and on March 26d. 14h. with Uranus. Mars is in conjunetion with Uranus on March 16. Neptune is in opposition on March 14, the distance from the earth being 2,716 million miles. The constellations of bright stars associated with winter evenings are now well westwards when the sky darkens after sunset. The regions of the sky which follows-Leo, Virgo, Ursa Major and Bootesthough less spectacular to the unaided eye, are of great interest on account of the rich fields of extragalactic nebulæ. With small or moderate optical aid, there is also a number of interesting double stars well worth examining, including Castor (separation of components $\left.3 \cdot 6^{\prime \prime}\right)$, $\gamma$ I.eonis $\left(4 \cdot 0^{\prime \prime}\right)$, $\xi$ Ursæ Majoris $\left(1 \cdot 7^{\prime \prime}\right), \gamma$ Virginis $\left(5 \cdot 7^{\prime \prime}\right), \zeta$ Ursæ Majoris $\left(14^{\prime \prime}\right)$ and $\zeta$ Herculis $\left(I \cdot I^{\prime \prime}\right)$. The last binary has a period of about 35 years and was discovered in 1782 by Sir William Herschel ; the greatest separation of its components is $1 \frac{1}{2}$. Under favourable conditions the Zodiacal Light may be seen after sunset during this month. On fine evenings when the moon is absent, it is also worth while looking for auroras, for in Mareh occurs one of the semi-yearly peaks in auroræ frequency. [All times are given in Universal Time; subtract 1 hour from Summer Time.]

\section{Announcements}

ThE University of Oxford has decided to confer the honorary degree of D.Se. on Dr. E. V. Appleton, formerly Wheatstone professor of physics at King's College, London, and Jacksonian professor of natural philosophy in the University of Cambridge. Dr. Appleton is now secretary of the Department of Scientific and Industrial Research.

Prof. A. L. Mellanby will deliver the Thomas Lowe Gray Lecture of the Institution of Mechanical Engineers on March 15, at 6 p.m. The title of the lecture will be "Fifty Years of Marine Engineering".

The Herbert Jackson Prize for 1939 of the L.M.S. Railway has been awarded to Mr. H. I. Andrews, of the Engineering Section, Research Department, Derby, for his paper entitled "The Development of a Refrigerating Machine for Use on Trains".
THE council of the Institution of Naval Architects has awarded the Premium of the Institution for the year 1939 to Mr. A. Nicholls, for his paper "The All-Welded Hull Construction of H.M.S. Seagull. The Wakeham Prize for 1939 has been awarded to Mr. A. Emerson, for his paper "The Effect of Shape of Bow on Ship Resistance (Part 2)"

Dr. WARfield T. Longcope, Baltimore, has been elected president of the board of directors of the Rockefeller Institute of Medical Research in succession to the late Dr. Charles R. Stockard.

The Alfred Denker Foundation Prize for 1939 has been awarded by the German Otorhinolaryngological Society to Dr. Lotar v. Hofmann, of Vienna, for a work on the influence of diseases of the ear and upper respiratory tract on the development of the infant and young child.

The Committee of the Physiological Society which was planning the Seventeenth International Congress of Physiology at Oxford in August 1941 under the presidency of Sir Charles Sherrington has decided, with regiet, that the Congress must be postponed. Arrangements for the future will be mads in consultation with the Fermanent International Committee.

The Central Association for Mental Welfare, in co-operation with the University Extension and Tutorial Classes Council, will, if sufficient applications are received, hold a course on mental deficiency at the London School of Hygiene, Keppel Street, W.C.I, from April 8 to 20. The lecturers will include Dr. A. F. Tredgold, Dr. Henry Herd and Miss Lucy Fildes. Further information can be obtained from Miss Evelyn Fox, c/o University Extension Department, at the School of Hygiene.

A RESEARCH scholarship of the value of $£ 250 \mathrm{a}$ year and tenable for two years has been founded by the Wrought Light Alloys Development Association to encourage and facilitate research in the application of light alloys to ship construction. The scholarship will be administered by a committee of the Institution of Naval Architects, and it is hoped to make the first award in September 1940. Full particulars of entry, which closes on July 31, can be obtained from the Secretary, Institution of Naval Architects, 10 Upper Belgrave Street, London, S.W.1.

A PRIZE of $£ 20$ with a diploma is awarded annually by the Council of the Royal Asiatic Society for an essay on some selected subject. The object is to encourage interest in the history and civilization of the East among non-Asiatics. In order to increase the basis of interest, the Council has decided to offer alternative subjects for the next competition. The two subjects are: (i) "Compare briefly the British, French and Dutch Systems of Administration in the East" ; (ii) "The Development of Modern Turkish Literature". An essay on either subject may be submitted, and must be in the hands of the secretary at 74 Grosvenor Street, W., by October 1 next. 